\title{
The Effect of Internal Marketing Implementations on the Organizational Citizenship Behaviors of Youth and Sports Directorate Employees
}

\author{
Mehdi DUYAN* \\ Inonu University, Faculty of Sport Science, Malatya, Turkey.
}

Original Article

Received: 04.03.2021
Accepted: 25.04.2021

DOI:10.25307/jssr.891016

Online Publishing: 30.06.2021

\begin{abstract}
Internal marketing and organizational citizenship issues have recently begun to be studied more in the literature. This study aimed to examine the effect of internal marketing practices on the organizational citizenship behavior of employees in the sports sector. Data were collected by simple random sampling method using an online survey tool and was obtained from Antalya, Karaman, Kütahya, Izmir, Istanbul, and Muğla Provincial Directorate of Youth and Sport of employees $(\mathrm{N}=224)$. As a data collection tool, the IM-11 scale developed by Yildiz and Kara (2017) was used to measure internal marketing, and the organizational citizenship behavior scale developed by Bolat, Bolat and Seymen (2009) was used to measure organizational citizenship behavior. Descriptive statistics, validity and reliability analysis, correlation analysis, and hierarchical regression analysis were used in the analysis of the data. The result of the analyses showed the significant and positive effect of internal marketing on organizational citizenship behavior. In other analyzes, while internal marketing had a significant and positive effect on the sportsmanship and civic virtue subscale of organizational citizenship behavior, no significant effect was observed on altruism, conscientiousness, and courtesy.

Keywords: Internal marketing, organizational citizenship behaviors, employee, youth and sports directorate.
\end{abstract}

\section{INTRODUCTION}

The basic purpose of public organizations in all societies is to provide services that will meet the demands, needs, and expectations of the people effectively and efficiently. In order to provide a public / customer-oriented service at the expected level, the employees (internal customers) of the organization should also be highly motivated and supported. Achieving service quality by meeting the demands, needs, and expectations of external customers who receive service from the organization is only possible if the demands, needs, and expectations of internal customers are satisfied by the organization. This approach is called internal marketing in the literature (Güven and Sadaklioglu, 2011).

Internal marketing, which emerged about half a century ago and is a fairly new concept for marketing literature, was first introduced in 1976 by Berry, Hensel and Burke. Then, this concept was studied by George in 1977, Thompson, Berry and Davidson in 1978, and Murray in 1979. Subsequently, this concept was explained in detail in an article written by Berry in 1981 (Yüce and Kavak, 2017). Berry (1988) made a distinction in the concept of the customer in his study on service organizations, and defined the people receiving service from the

\footnotetext{
* Corresponding Author: Assist. Prof. Dr. Mehdi DUYAN, Inonu University, Faculty of Sport Science e-mail: mehdi.duyan@inonu.edu.tr
} 
organization as "external customer" and the organization employee as "internal customer". In the literature, although there are many definitions of the concept of internal marketing, the definition of Berry and Parasuraman in 1991 was highlighted. According to the authors, "internal marketing is to meet the expectations and needs of the employees, the employee's commitment and motivation to the organization, whose needs are satisfied, increases positively". Among other factors, rewarding is one of the most important factors in maintaining the motivation of the internal customer at the highest level. Rewarding has particular importance in terms of keeping the morale of employees (internal customers) high and creating enthusiasm, thus creating high performance (Toksar1, 2012).

In today's environment where competition is increasing, organizations want to have employees who act meticulously in their duties, work without neglecting their jobs, and comply with the rules even when there is no supervision and control. Moreover, it needs employees who voluntarily help their colleagues, take additional tasks without obligation, stay away from gossip and take care to keep the secrets of the organization. Such behaviors of employees in the organization are called Organizational Citizenship Behaviors (OCB) (Karaman, Yücel \& Dönder, 2008). The concept of OCB was first introduced in a study in 1983 by Dennis W. Organ and Thomas S. Bateman. In this study, this concept is defined as "individual behavior that does not take place directly and explicitly in the formal reward system of the organization, helps the organization to work effectively and efficiently, and is based on volunteerism" (Organ, 1990). The common point emphasized by the definitions of OCB is that such behaviors of employees are optional and voluntary extra-role behaviors and that they contribute to organizational effectiveness (Sezgin, 2005). OCB is affected positively or negatively by many variables. For instance, while mobbing negatively affects the OCB of employees (Yildiz, 2016a), internal marketing can positively affect it.

Considering the OCB theoretically, it is seen that it is based on the foundations developed by the social exchange theory. Social exchange theory, developed by Blau in 1964, emphasizes social relations based on mutual benefit. In social exchange, the relations between the parties are not based on a specific obligation, but on the basis of volunteering (Karacaoğlu and Güney, 2010). The concept of OCB was first used by Bateman and Organ (1983) in the literature. According to Organ (1997), OCB consists of five subscales: altruism, courtesy, conscientiousness, sportsmanship, and civic virtue. Altruism is thinking about and helping other employees. For example, helping an employee with an issue that he/she cannot fully accomplish. Courtesy is helping other employees avoid problems that will affect their jobs. For example, helping prevent future problems from occurring (Podsakoff and MacKenzie, 1997). Conscientiousness is that employees are willing to exhibit behaviors beyond the minimum expected role behavior (Organ, 1990). For example, not to waste resources of the organizations. Sportsmanship is the behavior that involves employees avoiding negative behaviors that may cause tension and conflict in the work environment and not complain about insignificant problems (Organ, 1990). For example, one employee's tolerance to the other employee. Civil virtue refers to the behaviors of protecting the interests of the organization at the highest level, supporting the activities of the organization in professional and social contexts, participating voluntarily in the organization, and being involved with the organization (Allison, Voss and Dryer, 2001). On the other hand, civic virtue is defined as behaviors that indicate employees' participation in the political life of the organization, their commitment, and interest at the 
macro-level (Podsakoff, MacKenzie, Paine and Bachrach, 2000). In the literature, there are studies examining the impact of internal marketing on issues such as organizational commitment (Candan and Gündüz Çekmecelioğlu, 2009; Dokuzoğlu and Eren, 2020; Kocaman, Durna and İnal, 2013; Taşkın and Yeni, 2016; Tuncay, 2018; Yeniçeri, Kurt and Akgül, 2020; Yıldız, 2020), job satisfaction (Arslanoğlu, Bektemür and Gemlik, 2020; Baran and Arabelen, 2017; Eşitti and Buluk, 2018; Öngel and Şenol, 2019; Özçifçi, 2018; Yıldız, 2011), job performance (Duyan, 2020; Eşitti and Buluk, 2018), and OCB (Abzari and Ghujali, 2011; Eren, Kaygisiz and Katlav, 2016; Mülayim, 2013; Yildiz, 2016b). While the studies in the literature generally include studies aimed at determining the relations of internal marketing with different variables, it is seen that studies on OCB are not very common.

On the other hand, some of the studies are not directly related to sports organizations, but rather to different sectors and organizations. Sports organizations are seen as the most interesting sector in the service industry. Therefore, the increasing interest of people in the services offered by these organizations in the last two decades has increased the demand for these organizations. The proliferation and diversification of the organizations that produce these services have created competition in the sports sector as well as in other sectors (Dağlı Ekmekçi, 2019). In today's intense competition environment, organizations that succeed in the competition by providing service quality survive, while those who fail have to withdraw from the market. Therefore, it is stated that sports organizations are also faced with the necessity of developing more effective marketing strategies in order to sustain their lives and existence (Yildiz, 2014). Expectations of employees can be met through internal marketing, enabling them to show more production behavior (Barsulai, Makopondo and Fyava, 2019). OCB is an important element that is a source of increase in production in an organization. Thus, the performance of the organization may increase if the employees behave in favor of their organizations beyond their duties. When evaluated from this point of view, in order to give a healthy direction to economic activities, it is important to clarify the relationship between internal marketing and OCB of employees in sports organizations. While internal marketing and OCB studies are quite abundant in other sectors, the lack of similar studies in the context of sports organizations is considered a deficiency. Therefore, the findings obtained from this study will give an idea to sport management in terms of strategy development and will guide decision-makers to achieve high performance from employees. In order to contribute to both sports literature and the field of application, the following hypotheses have been developed to learn the relationship between internal marketing and OCB in the sports sector:

$\mathrm{H}_{1}$. Internal marketing has a significant and positive effect on employees' altruism.

$\mathrm{H}_{2}$. Internal marketing has a significant and positive effect on employees' conscientiousness.

$\mathrm{H}_{3}$. Internal marketing has a significant and positive effect on employees' courtesy.

$\mathrm{H}_{4}$. Internal marketing has a significant and positive effect on the employees' sportsmanship.

$\mathrm{H}_{5}$. Internal marketing has a significant and positive effect on employees' civic virtue.

$\mathrm{H}_{6}$. Internal marketing has a significant and positive effect on employees' organizational citizenship behaviors. 


\section{METHOD}

\section{Research Model}

The research model is shown in Figure 1. This model indicates the effects (cause and effect relationship) of internal marketing on OCB and its subscales, that is, the effects of independent variables on the dependent variable.

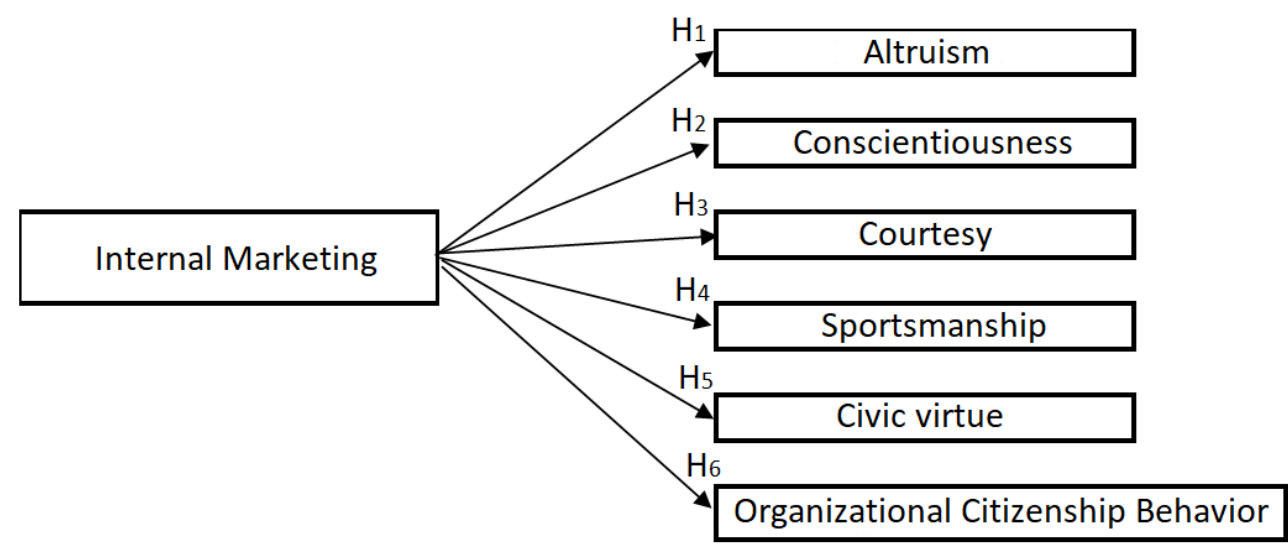

Figure 1. Research Model

\section{Participants}

The universe of this study was composed of Antalya, Karaman, Kütahya, İzmir, Malatya, and Muğla Provincial Directorates of Youth and Sports employees, in Turkey. The sample is composed of employees $(n=224)$ working in this organization. The data were collected using a simple random sampling method via online survey tool (Google forms).

\section{Measurement Instruments}

In this study, internal marketing and OCB scales were used as data collection tools. The IM11 scale developed by Yildiz and Kara (2017) was used to measure internal marketing, and the organizational citizenship behavior scale developed by Bolat, Bolat and Seymen (2009) was used to measure OCB. The IM-11 scale has one subscale and consists of 11 items. The OCB scale consists of 20 items and five subscales (Altruism, Conscientiousness, Courtesy, Sportsmanship, and Civic Virtue). Statements in both scales were measured with a 5-point Likert degree. The statements in the internal marketing scale are in the range of " $1=$ strongly disagree, 5 = strongly agree", and the statements in the OCB scale are in the range of " $1=$ Never, 5 = Always". "The fact that these scales were previously applied in a Turkish population and was found valid and reliable" was effective in choosing these scales.

\section{Research Ethic}

Ethical approval was given to this study by the Social and Humanities Scientific Research and Publication Ethics Committee of Inönü University, Turkey (with the decision number of 2020 / 6-14 at its meeting dated 13.08.2020).

\section{Statistical Analyses}

In this study, descriptive statistics were used to determine demographic characteristics of the participants, and correlation and regression analysis to determine the relationships between variables. 


\section{FINDINGS}

\section{Demographic Characteristics of the Participants}

According to demographic findings, $59.4 \%$ of the participants are male and $40.6 \%$ are female. $63.4 \%$ of the participants are single, $47.8 \%$ are in the " $31-40$ age" group, $61.6 \%$ have an "undergraduate degree". When analyzed in terms of working time variable in the organization; $40.2 \%$ of the participants have a period of " $1-5$ years" in working life, $72.3 \%$ of them work in "permanent status" (Table 1).

Table 1. Demographic characteristics

\begin{tabular}{llcc}
\hline Variables & & $\mathbf{f}$ & \% \\
\hline Gender & Female & 91 & 40.6 \\
& Male & 133 & 59.4 \\
\hline Marital status & Single & 142 & 63.4 \\
& Married & 82 & 36.6 \\
\hline Age & $21-30$ & 69 & 30.8 \\
& $31-40$ & 107 & 47.8 \\
& $41-50$ & 37 & 16.5 \\
& More than 51 & 11 & 4.9 \\
\hline Education & High school & 9 & 4.0 \\
& Undergraduate & 138 & 61.6 \\
& Graduate & 77 & 34.4 \\
\hline Tenure (years) & $1-5$ & 90 & 40.2 \\
& $6-10$ & 82 & 36.6 \\
& $11-15$ & 18 & 8.0 \\
& $16-20$ & 17 & 7.6 \\
& More than 21 & 17 & 7.6 \\
\hline Status & Permanent & 162 & 72.3 \\
& Fixed-term contract & 62 & 27.7 \\
\hline
\end{tabular}

\section{Validity and Reliability Analysis of the Scales}

Exploratory factor analysis was performed to determine the construct validity of the scales, and the Cronbach's Alpha coefficient was calculated to determine the reliability. According to the results of the validity analysis determined by the Varimax rotation method, factor loads of the internal marketing scale range between .574 and .854 , and the factor loads of the OCB scale range between .416 and .836 . Cronbach's Alpha value obtained as a result of the reliability analysis of the scales is .929 for internal marketing, .862 for OCB. These values show that the scales are highly reliable.

\section{Correlation Analysis}

Table 2 shows that there is a significant and positive relationship $(r=0.244 ; \mathrm{p}<0.001)$ between internal marketing and OCB. In the subscales of $\mathrm{OCB}$; significant and positive correlations were observed between internal marketing and sportsmanship $(0.209 ; p<0.001)$ and between internal marketing and civic virtue $(0.360 ; \mathrm{p}<0.001)$. On the other hand, although there was a positive relationship between internal marketing and altruism, conscientiousness, and courtesy, no significance was found. 
Table 2. Results of correlation analysis

\begin{tabular}{|c|c|c|c|c|c|c|}
\hline Variables & 1 & 2 & 3 & 4 & 5 & 6 \\
\hline 1. Internal marketing & 1 & & & & & \\
\hline 2. Altruism & .038 & 1 & & & & \\
\hline 3. Conscientiousness & .119 & $.357^{* *}$ & 1 & & & \\
\hline 4. Courtesy & .022 & $.451^{* *}$ & $.331^{* *}$ & 1 & & \\
\hline 5. Sportsmanship & $.209^{* *}$ & $.359^{* *}$ & $.329^{* *}$ & $.499^{* *}$ & 1 & \\
\hline 6. Civic Virtue & $.360^{* *}$ & $.326^{* *}$ & $.436^{* *}$ & $.320^{* *}$ & $.398^{* *}$ & 1 \\
\hline 7. Organizational citizenship behavior & $.244^{* *}$ & $.692^{* *}$ & $.659^{* *}$ & $.684^{* *}$ & $.728^{* *}$ & $.766^{* *}$ \\
\hline
\end{tabular}

\section{Hierarchical Regression Analysis}

The evaluations regarding the results of the two-step hierarchical regression analysis, where internal marketing is the independent variable and the OCB and its subscales are the dependent variables, were presented below.

Table 3 shows that internal marketing has no statistically significant effect on the altruism subscale $(\beta=0.039 ; \mathrm{p}>0.05)$.

Table 3. The results of hierarchical regression analysis for determining the relationships between altruism and independent variables

\begin{tabular}{lcccccc}
\hline \multirow{2}{*}{ Independent variables } & \multicolumn{3}{c}{ Step 1 } & \multicolumn{3}{c}{ Step 2 } \\
\cline { 2 - 7 } & $\boldsymbol{B e t a}$ & $\boldsymbol{t}$ & $\boldsymbol{p}$ & $\boldsymbol{B e t a}$ & $\boldsymbol{t}$ & $\boldsymbol{p}$ \\
\hline 1. Gender & .022 & .308 & .758 & .026 & .360 & .719 \\
2. Marital status & .025 & .347 & .729 & .021 & .291 & .772 \\
3. Age & .042 & .415 & .679 & .040 & .390 & .697 \\
4. Education & -.051 & -.714 & .476 & -.050 & -.696 & .487 \\
5. Tenure & -.006 & -.059 & .953 & -.002 & -.015 & .988 \\
6. Status & -.001 & -.015 & .988 & .000 & -.001 & .999 \\
7. Internal marketing & - & - & - & .039 & .570 & .569 \\
\hline$F$ & & .213 & & & .228 & \\
$R^{2}$ & & .006 & & & .007 & \\
Adjusted $R^{2}$ & -.022 & & & -.025 & \\
\hline
\end{tabular}

Note: Standardized beta values were used.

Table 4 indicates that internal marketing has no statistically significant effect on the conscientiousness subscale $(\beta=0.097 ; \mathrm{p}>0.05)$.

Table 4. The results of hierarchical regression analysis for determining the relationships between conscientiousness and independent variables

\begin{tabular}{|c|c|c|c|c|c|c|}
\hline \multirow{2}{*}{ Independent variables } & \multicolumn{3}{|c|}{ Step 1} & \multicolumn{3}{|c|}{ Step 2} \\
\hline & Beta & $t$ & $p$ & Beta & $t$ & $p$ \\
\hline 1. Gender & -.078 & -1.120 & .264 & -.069 & -.984 & .326 \\
\hline 2. Marital status & .056 & .791 & .430 & .046 & .653 & .514 \\
\hline 3. Age & -.045 & -.443 & .658 & -.051 & -.505 & .614 \\
\hline 4. Education & -.096 & -1.358 & .176 & -.093 & -1.321 & .188 \\
\hline 5. Tenure & -.110 & -1.039 & .300 & -.098 & -.928 & .354 \\
\hline 6. Status & -.075 & -.966 & .335 & -.072 & -.932 & .353 \\
\hline 7. Internal marketing & - & - & - & .097 & 1.435 & .153 \\
\hline$F$ & & 1.252 & & & 1.372 & \\
\hline$R^{2}$ & & .033 & & & .043 & \\
\hline Adjusted $R^{2}$ & & .007 & & & .012 & \\
\hline
\end{tabular}

Note: Standardized beta values were used. 
Table 5 shows that internal marketing has no statistically significant effect on the courtesy subscale $(\beta=0.022 ; \mathrm{p}>0.05)$.

Table 5. The results of hierarchical regression analysis for determining the relationships between courtesy and independent variables

\begin{tabular}{|c|c|c|c|c|c|c|}
\hline \multirow{2}{*}{ Independent variables } & \multicolumn{3}{|c|}{ Step 1} & \multicolumn{3}{|c|}{ Step 2} \\
\hline & Beta & $t$ & $p$ & Beta & $t$ & $p$ \\
\hline 1. Gender & -.018 & -.261 & .795 & -.016 & -.230 & .818 \\
\hline 2. Marital status & -.024 & -.336 & .737 & -.026 & -.363 & .717 \\
\hline 3. Age & .048 & .465 & .642 & .046 & .451 & .653 \\
\hline 4. Education & .025 & .351 & .726 & .026 & .359 & .720 \\
\hline 5. Tenure & -.042 & -.394 & .694 & -.040 & -.368 & .713 \\
\hline 6. Status & .013 & .161 & .873 & .013 & .168 & .867 \\
\hline 7. Internal marketing & - & - & - & .022 & .314 & .754 \\
\hline$F$ & \multicolumn{3}{|c|}{.102} & \multicolumn{3}{|c|}{.101} \\
\hline$R^{2}$ & \multicolumn{3}{|c|}{.003} & \multicolumn{3}{|c|}{.003} \\
\hline Adjusted $R^{2}$ & \multicolumn{3}{|c|}{-.025} & \multicolumn{3}{|c|}{-.029} \\
\hline
\end{tabular}

Note: Standardized beta values were used.

Table 6 indicates that the sportsmanship subscale is significantly and positively affected by internal marketing $(\beta=0.218 ; \mathrm{p}<0.01)$ and is explained at the .09 level.

Table 6. The results of hierarchical regression analysis for determining the relationships between sportsmanship and independent variables

\begin{tabular}{|c|c|c|c|c|c|c|}
\hline \multirow{2}{*}{ Independent variables } & \multicolumn{3}{|c|}{ Step 1} & \multicolumn{3}{|c|}{ Step 2} \\
\hline & Beta & $t$ & $p$ & Beta & $t$ & $p$ \\
\hline 1. Gender & $.160 *$ & 2.313 & .022 & $.181 *$ & 2.662 & .008 \\
\hline 2. Marital status & .036 & .508 & .612 & .014 & .205 & .838 \\
\hline 3. Age & .173 & 1.722 & .086 & .159 & 1.620 & .107 \\
\hline 4. Education & .026 & .366 & .715 & .032 & .467 & .641 \\
\hline 5. Tenure & -.204 & -1.940 & .054 & -.178 & -1.725 & .086 \\
\hline 6. Status & -.015 & -.191 & .849 & -.008 & -.112 & .911 \\
\hline 7. Internal marketing & - & - & - & $.218 * *$ & 3.299 & .001 \\
\hline$F$ & \multicolumn{3}{|c|}{1.544} & \multicolumn{3}{|c|}{2.938} \\
\hline$R^{2}$ & \multicolumn{3}{|c|}{.041} & \multicolumn{3}{|c|}{.087} \\
\hline Adjusted $R^{2}$ & \multicolumn{3}{|c|}{.014} & \multicolumn{3}{|c|}{.057} \\
\hline
\end{tabular}

Table 7 shows that the civic virtue subscale is significantly and positively affected by internal marketing $(\beta=0.349 ; p<0.001)$ and is explained at the 0.15 level.

Table 7. The results of hierarchical regression analysis for determining the relationships between civic virtue and independent variables

\begin{tabular}{|c|c|c|c|c|c|c|}
\hline \multirow{2}{*}{ Independent variables } & \multicolumn{3}{|c|}{ Step 1} & \multicolumn{3}{|c|}{ Step 2} \\
\hline & Beta & $t$ & $p$ & Beta & $t$ & $p$ \\
\hline 1. Gender & -.011 & -.154 & .878 & .023 & .347 & .729 \\
\hline 2. Marital status & .093 & 1.313 & .191 & .058 & .871 & .385 \\
\hline 3. Age & -.033 & -.328 & .743 & -.055 & -.581 & .562 \\
\hline 4. Education & .060 & .855 & .393 & .070 & 1.065 & .288 \\
\hline 5. Tenure & -.088 & -.834 & .405 & -.046 & -.465 & .642 \\
\hline 6. Status & .004 & .047 & .963 & .014 & .187 & .852 \\
\hline 7. Internal marketing & - & - & - & $.349 * *$ & 5.491 & .000 \\
\hline$F$ & & 1.315 & & & 5.585 & \\
\hline$R^{2}$ & & .035 & & & .153 & \\
\hline Adjusted $R^{2}$ & & .008 & & & .126 & \\
\hline
\end{tabular}


Table 8 indicates that the OCB is significantly and positively affected by internal marketing ( $\beta$ $=0.238 ; \mathrm{p}<0.001)$ and is explained at the 0.07 level.

Table 8. The results of hierarchical regression analysis for determining the relationships between organizational citizenship behavior and independent variables

\begin{tabular}{|c|c|c|c|c|c|c|}
\hline \multirow{2}{*}{ Independent variables } & \multicolumn{3}{|c|}{ Step 1} & \multicolumn{3}{|c|}{ Step 2} \\
\hline & Beta & $t$ & $p$ & Beta & $t$ & $p$ \\
\hline 1. Gender & .028 & .393 & .694 & .050 & .734 & .464 \\
\hline 2. Marital status & .062 & .858 & .392 & .038 & .538 & .591 \\
\hline 3. Age & .050 & .488 & .626 & .035 & .350 & .727 \\
\hline 4. Education & .001 & .012 & .990 & .008 & .113 & .910 \\
\hline 5. Tenure & -.129 & -1.209 & .228 & -.101 & -.964 & .336 \\
\hline 6. Status & -.017 & -.217 & .828 & -.010 & -.134 & .894 \\
\hline 7. Internal marketing & - & - & - & $.238 * *$ & 3.569 & .000 \\
\hline$F$ & \multicolumn{3}{|c|}{.525} & \multicolumn{3}{|c|}{2.294} \\
\hline$R^{2}$ & \multicolumn{3}{|c|}{.014} & \multicolumn{3}{|c|}{.069} \\
\hline Adjusted $R^{2}$ & \multicolumn{3}{|c|}{-.013} & \multicolumn{3}{|c|}{.039} \\
\hline
\end{tabular}

\section{DISCUSSION AND CONCLUSION}

There are many studies in the literature investigating the effects of internal marketing on many variables, but studies on the relationship between internal marketing and OCB are limited. Therefore, we believe that the results of the relationship between the two variables included in this study will contribute to the literature. Hence, the findings of this study examining the effects of internal marketing applied in organizations on OCB subscales will guide other studies.

In most of the empirical studies conducted in various service sectors, it was seen that there was a positive and significant relationship between internal marketing and OCB (Alper Ay, 2018; Alshurideh, Alhadid and Barween, 2015; Chang, Tseng and Chen, 2012; Seyed Javadin, Rayej, Yazdani, Estiri and Aghamiri, 2012; Yildiz, 2016b). Our study on employees in the sports industry has shown that, similar to other research, internal marketing affects OCB significantly and positively. However, the regression analysis results in our study showed that internal marketing had significant and positive effects on the subscales of the OCB, such as sportsmanship and civic virtue, on the other hand, it did not have any significant effect on altruism, conscientiousness, and courtesy. This has revealed that some internal marketing practices within the organization have an effect on the prosocial behavior of the employees, while some internal marketing practices do not affect the prosocial behavior of the employees. This situation can be explained as follows. Youth and sports organizations in Turkey, through the 703 numbered Decree-Law, under the "Higher Education Credit and Hostels Institution" and "Youth Services and Sports Provincial Directorate" reorganized together under a single roof, and it has been changed the management structure importantly. This situation may have caused positive or negative prosocial behaviors due to the coming together of employees and managers with different working cultures. There are studies in the literature that the organizational culture (support, innovation, goals, rules) contributes differently to internal marketing practices (Chang et al., 2012). In short, the lack of internal marketing effects in some sub-dimensions of OCB such as altruism, conscientiousness, and courtesy can be attributed to the different expectations of employees. 
A number of attitudes and behaviors are followed among the employees in the organization, which from time to time may constitute an obstacle to the functioning and goals of the organization and at the same time reduce the performance of the organization. These behaviors generally go against the norms and values of the organization. Such behaviors not only harm organizational goals and objectives but also negatively affect the work and even daily lives of employees. In work environments where negative behaviors are experienced intensely and not well managed, an employee who feels unhappy psychologically may exhibit negative behaviors towards his organization and job, and therefore work performance may decrease (Varışl1, 2020). Obviously, in order for organizations to exhibit high performance and to ensure their satisfaction by providing quality service to the public, the organization must, first of all, maintain healthy communication and relations with its employees and motivate them. In this framework, organization managers should give importance to the human resources application methods used by the private sector beyond the classical personnel management approach (Barcan and Barcan, 2018). One of these methods, the understanding of internal marketing, should be transformed into a culture, and it should aim to increase the quality of the service offered by the organization by ensuring the satisfaction of the employees, who are called internal customers (Güven and Sadaklıoğlu, 2011). Ensuring the motivation of employees by meeting their needs and expectations can only be achieved by giving importance to internal marketing activities by the management. Therefore, the OCB of employees whose needs and expectations are met through internal marketing will also increase (Alper Ay, 2018).

The results of this study showed that internal marketing had an effect on the OCB. However, not all of the sub-dimensions of OCB had been affected the same from internal marketing. Therefore, it can be said that more studies are needed to determine whether these results are consistent in different samples. Additionally, in future research, researchers can similarly examine the relationship between internal marketing, prosocial behavior, and job satisfaction in different units of the sports industry.

Conflicts of Interest: The author declares that no conflict of interest in the publication of this article.

Author Contribution: This study has been researched and concluded in accordance with scientific and ethical rules; I also declare that I am responsible for the entire study from the creation, design, data collection and processing, analysis and interpretation of the study idea.

\section{Research Ethic}

Ethics Committee : Social and Humanities Scientific Research and Publication Ethics Committee of Inonu University

Date $\quad: 13.08 .2020$

Decision / Protocol number : 2020 / 6-14 
Duyan, M. (2021). The effect of internal marketing implementations on the organizational citizenship behaviors of youth and sports directorate employees. Journal of Sport Sciences Researches, 6(1), 76-87.

\section{REFERENCES}

Abzari, M. \& Ghujali, T. (2011). Examining the impact of internal marketing on organizational citizenship behavior. International Journal of Marketing Studies, 3(4), 95-104. DOI: 10.5539/IJMS.V3N4P95

Allison, B. J., Voss, R. S. \& Dryer, S. (2001). Student classroom and career success: The role of organizational citizenship behavior. Journal of Education for Business, 76(5), 282-288. https://doi.org/10.1080/08832320109599650

Alper Ay, F. (2018). The effects of internal marketing activities on organizational citizenship behavior. Journal of International Health Sciences and Management, 4 (7), 31-49.

Alshurideh, M., Alhadid, A. Y. \& Barween, A. (2015). The effect of internal marketing on organizational citizenship behavior an applicable study on the university of Jordan employees. International Journal of Marketing Studies, 7(1), 138-145. DOI:10.5539/ijms.v7n1p138

Arslanoğlu, A., Bektemür, G. \& Gemlik, N. (2020). İçsel pazarlamanın çalışanların iş tatmini üzerine etkisi. Săgllk ve Sosyal Refah Araştırmaları Dergisi, 2(2), 22-34.

Baran, E. \& Arabelen, G. (2017). İçsel pazarlamanın gemi acentelerinin iş tatmini üzerindeki etkisi: Nicel bir araştırma. Dokuz Eylül Üniversitesi Denizcilik Fakültesi Dergisi, 9(1), 2554. https://doi.org/10.18613/deudfd.321567

Barcan, M. \& Barcan, L. (2018). The importance of the application of modern human resources management methods to the level of healh organizations. In B.M. Popa (Ed.), Defense Resources Management in the $21^{\text {st }}$ Century, (pp 25-32). Braşov, Romania: National Defense University, "Carol I" Publishing House.

Barsulai, S.C., Makopondo, R.O.B. \& Fyava, E.W.O. (2019). Effect of organizational citizenship behavior on employee productivitiy in star rated hotels in Kenya. European Journal of Hospitality and Tourism Research, 7(1), 1-8.

Bateman, T.S. \& Organ, D.W. (1983). Job satisfaction and the good soldier: The relationship between affect and employee “citizenship". Academy of Management Journal, 26(4), 587-595. https://doi.org/10.5465/255908

Berry, L.L. \& Parasuraman, A. (1991). Marketing services: Competing through Quality. The Free Press, New York.

Berry, N.C. (1988). Revitalizing brands. Journal of Consumer Marketing, 5(3), 15-20. https://doi.org/10.1108/eb008228

Bolat, O.İ., Bolat, T. \& Seymen, O.A. (2009). Güçlendirici liderlik davranışları ve örgütsel vatandaşlık arasındaki ilişkilerin sosyal mübadele kuramından hareketle incelenmesi. Ballkesir Üniversitesi Sosyal Bilimler Enstitüsü Dergisi, 12(21), 215-239.

Candan, B. \& Gündüz Çekmecelioğlu, H. (2009). İçsel pazarlama faaliyetlerinin örgütsel bağl1lık unsurları açısından değerlendirilmesi: Bir araştırma. Yönetim Dergisi: İstanbul Üniversitesi Isşletme Fakültesi Işsletme Íktisadı Enstitüsü, 20(63), 41-58.

Chang, C. C., Tseng, K. H. \& Chen, C. W. (2012). The moderating role of online community participation in the relationship between internal marketing and organizational citizenship behavior. Social Behavior and Personality: An International Journal, 40(10), 1725-1738. DOI: 10.2224/sbp.2012.40.10.1725

Dağlı Ekmekçi, Y.A. (2019). Factors influencing competitive advantage of sports clubs in Turkey. Trakya University Journal of Social Science, 21, 79-91. DOI: 10.26468/trakyasobed.423422

Dokuzoğlu, G. \& Eren, M. Ö. (2020). The effect of internal marketing on physical education and sports teachers' organizational commitment. European Journal of Education Studies, 6(12), 125-133.

Duyan, M. (2020). The effect of internal marketing on physical education and sports teachers' job performance. European Journal of Education Studies, 7(4), 269-276. DOI: 10.5281/zenodo.3824330 
Eren, D., Kaygisiz, N. \& Katlav, E. Ö. (2016). İçsel pazarlama uygulamalarının hizmet kalitesi üzerindeki etkisinde örgütsel vatandaşlık davranışının aracılık rolü. TURAN: Stratejik Araştırmalar Merkezi, 8(32), 493-498.

Eşitti, B. \& Buluk, B. (2018). İçsel pazarlama faaliyetlerinin iş performansına etkisinde iş tatmininin aracı rolü: Beş yıldızlı konaklama işletmeleri örneği. Akademik Araştırmalar ve Çalışmalar Dergisi, 10(18), 288-303. https://doi.org/10.20990/kilisiibfakademik.428696

Güven, A. \& Sadaklığlu, H. (2011). İnsan kaynakları yönetiminde içsel pazarlama anlayışı: Bir kamu kurumu üzerinde uygulama. Z.Parlak \& İ.G.Yumuşak (Ed.), Uluslararası 9. Bilgi, Ekonomi ve Yönetim Kongresi bildiriler kitabı içinde (ss. 2503-2517). Saraybosna: Bosna Hersek.

Karacaoğlu, K. \& Güney, Y. (2010). Öğretmenlerin örgütsel bağlılıklarının, örgütsel vatandaşlık davranışları üzerindeki etkisi: Nevşehir ili örneği. Öneri Dergisi, 9(34), 137-153.

Karaman, K., Yücel, C. \& Dönder, H. (2008). Öğretmen görüşlerine göre, okullardaki bürokrasi ile örgütsel vatandaşlık arasındaki ilişki. Kuram ve Uygulamada Ĕ̆itim Yönetimi, 53(53), $49-74$.

Kocaman, S., Durna, U. \& İnal, M. E. (2013). Konaklama işletmelerinde içsel pazarlama uygulamalarının örgütsel bağlılı̆̆a etkisi: Alanya örneği. Uluslararası Alanya İsletme Fakültesi Dergisi, 5(1), 21-29.

Mülayim, A. (2013). İçsel pazarlamanın örgütsel vatandaşlık davranışına etkileri üzerine Altın Çini \& Seramik $A S ̧$ 'de bir araştırma. Yüksek Lisans Tezi, Dumlupınar Üniversitesi, Sosyal Bilimler Enstitüsü, İşletme Anabilim Dalı, Kütahya.

Öngel, V. \& Şenol, Ş. (2019). İçsel pazarlama uygulamalarının çalışanların iş tatmini üzerine etkisi ve örgütsel adaletin aracilık rolü. Akademik Hassasiyetler, 6(12), 445-475.

Organ, D. W. (1990). The motivational basis of organizational citizenship behavior. Research in organizational behavior, 12(1), 43-72.

Organ, D. W. (1997). Organizational citizenship behavior: It's construct clean-up time. Human performance, 10(2), 85-97. https://doi.org/10.1207/s15327043hup1002_2

Özçifçi, V. (2018). İçsel pazarlama uygulamalarının iş tatminine etkisi: Hastane çalışanlarına yönelik bir uygulama. Ekonomik ve Sosyal Araştırmalar Dergisi, 14, 147-162.

Podsakoff, P. M. \& MacKenzie, S. B. (1997). Impact of organizational citizenship behavior on organizational performance: A review and suggestion for future research. Human performance, 10(2), 133-151. https://doi.org/10.1207/s15327043hup1002_5

Podsakoff, P. M., MacKenzie, S. B., Paine, J. B. \& Bachrach, D. G. (2000). Organizational citizenship behaviors: A critical review of the theoretical and empirical literature and suggestions for future research. Journal of management, 26(3), 513-563. https://doi.org/10.1016/S0149-2063(00)00047-7

Seyed Javadin, S., Rayej, H., Yazdani, H., Estiri, M. \& Aghamiri, S. A. (2012). How organizational citizenship behavior mediates between internal marketing and service quality. International Journal of Quality \& Reliability Management, 29(5), 512-530. https://doi.org/10.1108/02656711211230508

Sezgin, F. (2005). Örgütsel vatandaşlık davranışları: Kavramsal bir çözümleme ve okul açısından bazı çıkarımlar. Gazi Üniversitesi Gazi Eğitim Fakültesi Dergisi, 25(1), 317-339.

Taşkın, E. \& Yeni, Z. (2016). İçsel pazarlama faaliyetlerinin örgütsel bağlılık üzerindeki etkisini belirlemeye yönelik bir araştırma. Kastamonu University Journal of Economics \& Administrative Sciences Faculty, 11(1), 62-86.

Toksarı, M. (2012). İçsel pazarlama bağlamında, iç müşterinin çalıştığg iş yerinden tatmin olma düzeyi ile demografik özellikleri arasındaki farklılıkların tespitine yönelik ampirik bir çalışma. Sosyal Bilimler Enstitüsü Dergisi, 1(32), 155-183.

Tuncay, A. H. (2018). İçsel pazarlamanın örgütsel bağlılığa etkisi. Suleyman Demirel University Journal of Faculty of Economics \& Administrative Sciences, 23(4), 1287-1303. 
Varışlı, N. (2020). Örgütsel vatandaşlık faktörlerinden nezaket davranışının, çalışanların hizmet kalitesine etkilerinin analizi. İşletme Araştırmaları Dergisi, 12(3), 3089-3109.

Yeniçeri, T., Kurt, P. \& Akgül, V. (2020). İçsel pazarlama uygulamalarının örgütsel bağlılığa etkisinde iş tatmininin aracı rolü: Bankacılık sektöründe bir araştırma. Business \& Management Studies: An International Journal, 8(1), 476-501. https://doi.org/10.15295/bmij.v8i1.1357

Yıldız, S. M. (2011). İçsel pazarlama, iş tatmini ve örgütsel bağlılık ilişskisi: Spor okullarında görev yapan antrenörler üzerine bir inceleme. Selçuk Üniversitesi Beden Ĕgitimi ve Spor Bilim Dergisi, 13(2), 216-225.

Yildiz, S. M. (2016b). The effect of internal marketing on organizational citizenship behavior of academic staff in higher educational institutions. Universal Journal of Educational Research, 4(5), 1122-1128. DOI: 10.13189/ujer.2016.040523

Yıldız, S. M. (2020). İçsel pazarlamanın çalışanların örgütsel bağlılığına etkisi: Spor hizmeti sunan kamu kurumlarında bir alan çalışması. Sosyal ve Beşeri Bilimler Araştırmaları Dergisi, 21(46), 57-69.

Yıldız, S.M. (2016a). İşyerinde mobbing davranışlarının spor ve fiziksel etkinlik işletmeleri çalışanlarının örgütsel vatandaşlık davranışına etkisi. Dokuz Eylül Üniversitesi Sosyal Bilimler Enstitüsü Dergisi, 18(1), 165-180.

Yildiz, S.M. \& Kara, A. (2017). A Unidimensional instrument for measuring internal marketing concept in the higher education sector: IM-11 scale. Quality Assurance in Education, 25(3), 343-361. https://doi.org/10.1108/QAE-02-2016-0009

Yildiz, S.M. (2014). The role of internal marketing on job satisfaction and turnover intention: An empirical investigation of sport and physical activity organizations. Ege Academic Review: Business Administration, International Relations and Political Science, 14(1), 137-146.

Yüce, A. \& Kavak, O. (2017). The influence of internal marketing activities on organizational commitment and turnover intention: A research. In D.K. Dimitrov, D.Nikoloski, R.Y1lmaz (Eds.), IV. International Balkan and Near Eastern Social Sciences Congress Series (pp 315-332). Russe, Bulgaria: University of Agribusiness and Rural Development.

Except where otherwise noted, this paper is licensed under a Creative Commons Attribution 4.0 International license. 